\title{
Primer komplementdefektusok által okozott atípusos haemolyticus uraemiás szindróma
}

\author{
Reusz György dr. \\ Semmelweis Egyetem, Általános Orvostudományi Kar, I. Gyermekgyógyászati Klinika, Budapest
}

\begin{abstract}
A komplementrendszer a szervezet egyik legősibb veleszületett védekezőmechanizmusa, mely az ellenanyagokat és a phagocytasejtek múködését segíti, ezzel fontos szerepet játszik a mikroorganizmusok és az elhalt sejtek eltakarításában. A komplementrendszer múködészavara autoimmun betegségek és fertőzések kialakulásához vezet. A rendszer szabályozási hibájának következménye pedig az ellenőrizetlen komplementaktiváció és thromboticus microangiopathia kialakulása, következményes sokszervi érintettséggel. Munkánkban röviden áttekintjük a rendszer különböző aktivációs útjait, kiemelten foglalkozunk az alternatív út néhány komponensének primer, genetikai defektusával és - a legújabb nemzetközi ajánlások és irányelvek alapján - az atípusos haemolyticus uraemiás szindróma (aHUS) kialakulásával, diagnózisának és terápiájának alapelveivel. Végül, H-faktor-ellenes antitestek által kiváltott aHUS-esetek ismertetésével mutatjuk be a komplementdiagnosztika és a genetikai vizsgálatok meghatározó szerepét a betegség ellátásában.
\end{abstract}

Orv Hetil. 2018; 159(23): 929-936.

Kulcsszavak: haemolyticus uraemiás szindróma, komplement, komplementblokád, komplementfaktor-H

\section{Atypical hemolytic uremic syndrome caused by primary complement defects}

Complement is one of the most archaic parts of the innate immune system, which enhances the ability of antibodies and phagocytic cells to clear cell debris, and microorganisms. The complement system promotes inflammation and attacks the pathogen's plasma membrane. Malfunction of the system may lead to the development of autoimmunity or uncontrolled infections. Further, dysregulation of the tightly controlled complement activation process may lead to thrombotic microangiopathies with consequent multiorgan involvement. The present paper gives a short overview of the different pathways of complement activation. It focuses on primary genetic defects of components of the alternative pathway that result in dysregulation as well as on pathomechanism, classification, diagnostics and treatment of atypical hemolytic uremic syndrome (aHUS) based on the most recent international recommendations and guidelines. Finally the critical role of complement in host immunity and genetic diagnostics of complement deficiencies are illustrated with two cases of aHUS.

Keywords: hemolytic uremic syndrome, complement, complement blockade, complement factor $\mathrm{H}$

Reusz Gy. [Atypical hemolytic uremic syndrome caused by primary complement defects]. Orv Hetil. 2018; 159(23): 929-936.

(Beérkezett: 2018. január 8.; elfogadva: 2018. január 28.)

\section{Rövidítések}

ADAMTS13 = a disintegrin and metalloproteinase with a thrombospondin type 1 motif, member 13; aHUS = atípusos HUS; DAF $=$ (decay accelerating factor) lebomlást gyorsító faktor; $\mathrm{HRF}=($ homologue restriction factor $)$ homológ restrikciós faktor; HUS = haemolyticus uraemiás szindróma; IL = interleukin; $\mathrm{KR}=$ komplementrendszer; MASP1, -2 = (mannose binding lectin associated serine protease 1,2) mannózkötő lektin asszociálta szerin-proteáz- $1,-2 ; \mathrm{MBL}=($ mannose binding lectin) mannózkötő lektin; MCP = (membrane cofactor protein) membránkofaktor protein; STEC $=$ (Shiga toxin producing Escherichia coli) Shiga-toxin-termelö Escherichia coli; TMA = thromboticus microangiopathia; ULvWF = (unusually large Von Willebrand factor) szokatlanul nagy von Willebrand-faktor 
A komplementrendszer (KR) a szervezet egyik legősibb immunmechanizmusa, a veleszületett immunitás része. Múködészavara esetén károsodhat az egyes kórokozókra adott immunválasz, másrészt kóros múködése autoimmun betegségek kialakulására hajlamosít. Az utóbbi évek kutatásai a KR szabályozásával kapcsolatos új összefüggéseket tártak fel, amelyek új alapokra helyezték néhány ritka, thromboticus microangiopathiával járó kórkép diagnosztikáját és terápiáját [1-4]. A jelen összefoglaló ezen új ismeretek birtokában tárgyalja a haemolyticus uraemiás szindróma (HUS) klinikumát és patomechanizmusát.

A HUS három vezető tünete az intravasalis haemolysis, a thrombocytopenia és az akut vesefunkció-romlás [5]. A betegség patomechanizmusának középpontjában a thromboticus microangiopathia áll. Ennek kialakulásához számos kórfolyamat vezethet (1. ábra). Az új ismeretek alapján ma már érthető, hogy a nagyon hasonló kórképek korábbi empirikus kezelése miért volt sokszor sikertelen vagy rossz hatásfokú, hiszen a kórfolyamatok egészen eltérő, célzott kezelést igényelnek, a nem meg- felelő terápia adott esetben még ronthatja is a beteg állapotát [6-8].

E helyütt kizárólag a HUS és ezen belül kiemelten a primer komplementdefektusokra visszavezethető atípusos HUS (aHUS) kialakulását és az ezzel kapcsolatos diagnosztikus és terápiás következményeket tárgyaljuk. Esetismertetések kapcsán tekintjük át az elméleti ismeretek gyakorlati alkalmazásának nehézségeit.

\section{A KR felépítése}

A KR a vérben és az egyéb testfolyadékokban levő, kaszkádszerúen múködő szerin-proteáz-rendszer, amelyet összességében több mint 45 ismert fehérje alkot. Az aktiváció az úgynevezett klasszikus, az alternatív és a lektinindukált úton indulhat el [1]. A KR-nek alapvető szerepe van a patogének, immunkomplexek, elpusztult sejtek eltakarításában. Aktiválódása során a gyulladásos választ jelentősen fokozó peptidek keletkeznek, ugyanakkor a rendszert szabályozó, az aktiválódást gátló inhibitoro-

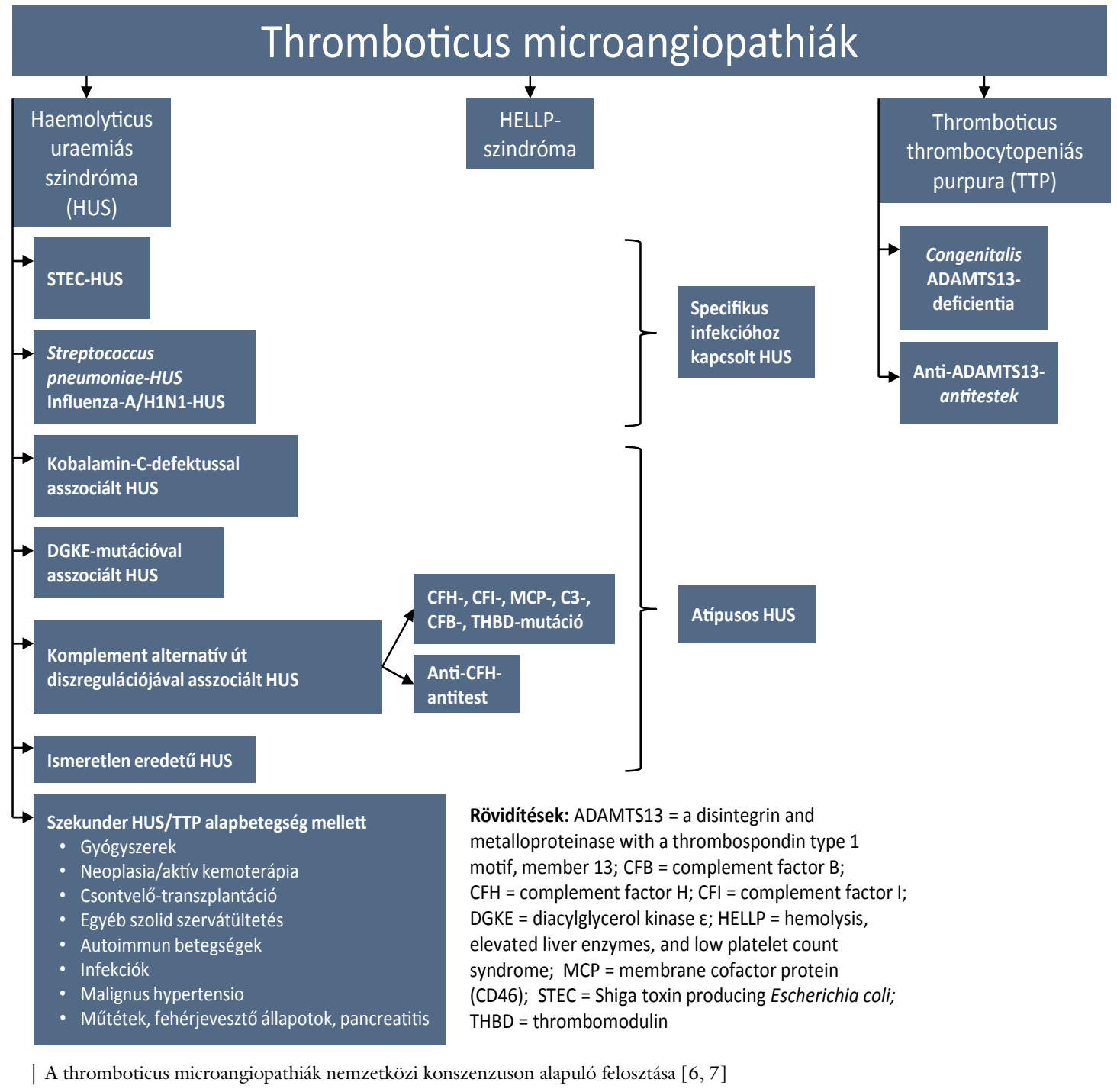


kat, valamint a szervezet saját sejtjeinek oldását gátló membránfehérjéket is magában foglal [1].

A klasszikus aktivációs út és a membránkárosító komplex elemeit $\mathrm{C}$ betûvel és azt követő arab számmal jelöljük: Clq, Clr, Cls, C4, C2, C3, C5, C6, C7, C8 és C9 (felsorolás az aktiválódás sorrendjében). A hasítás eredményeként általában az adott elemből keletkező kisebb fragmentumot „a"-val (C4a, C3a stb.), a nagyobbat „b”-vel jelöljük (például C3b, C4b stb.). Kivételt képez a C2, ahol a C2a a nagyobb, míg a C2b a kisebb aktivációs fragmentum. Az alternatív út komponenseit faktornak nevezzük: H-faktor, B-faktor, D-faktor, illetve a properdint P-vel jelöljük.

A lektinút alkotóelemeinek rövidítései a fehérjék funkciójára utalnak: mannózkötő lektin (mannose binding lectin - MBL), illetve az azzal reagáló enzimek, MASP1, -2 (mannose binding lectin associated serine protease 1,2 ).

A sejtfelszíni szabályozómolekulák nevének rövidítése általában szintén a múködésre utal: DAF (decay accelerating factor), MCP (membrane cofactor protein), HRF (homologue restriction factor). A membránt károsító komplex hatásának mérséklésében, illetve szabályozásában egyebek mellett a vitronektin, a kluszterin és a CD59 tölt be fontos szerepet [1].

A komplementrendszer alternatív útjának szabályozásában kiemelt szerepe van a $\mathrm{H}$ - és az I-faktornak $(\mathrm{CFH}$, CFI). Mindkét fehérjét döntően a máj termeli. A CFH feladata a C3-konvertáz gátlása és - kofaktorként - a CFI segítése. A CFI az alternatív és a klasszikus utak szabályozásában egyaránt részt vesz, a C3b és C4b alfa-láncát hasítja kofaktor jelenlétében. A membránkofaktor protein (MCP, más nómenklatúrával CD46) a vörösvérsejteken kívül minden más sejten expresszálódó, transzmembrán glikoprotein, a CFI múködéséhez szükséges sejtfelszíni kofaktor $[1,4]$.

\section{A HUS kialakulásának középpontjában az endothel károsodása és a komplementaktiváció áll}

A HUS-ban kialakuló thromboticus microangiopathia (TMA) következményei minden parenchymás szervet érinthetnek. A diagnosztikus triádhoz, az adott szervek mikrocirkulációjának zavara következtében, csatlakozhatnak egyebek mellett központi idegrendszeri tünetek (konvulzió, eszméletvesztés), myocardialis laesio, pancreasérintettség, diabetes, pulmonalis tünetek, rhabdomyolysis $[2,6,8]$. A HUS az endothelkárosodás mechanizmusa alapján két nagy betegségcsoportra osztható.

\section{Infekció köpetkeztében létrejövő HUS}

Idesoroljuk a verotoxint termelő bélbaktériumok (Shiga toxin producing Escherichia coli, STEC), illetve a neuraminidázt termelő Streptococcus pneumoniae kiváltotta HUS-t. STEC esetében a baktérium által termelt toxin a keringésbe jutva, majd az endothelhez kötődve a fehérjeszintézis gátlásán keresztül, közvetlenül toxikus hatású. Emellett a fehérvérsejt-, a thrombocyta- és véralvadási rendszer aktivációja, a citokin- (IL6-, IL8-, TNF-) hatás, a stimulált endothelből megnövekedett ULvWF- (unusually large Von Willebrand factor) kiáramlás, valamint a másodlagos ADAMTS13- (a disintegrin and metalloproteinase with a thrombospondin type 1 motif, member 13) enzim-konszumpció is szerepet játszik a kóros következményekben [9]. A toxintermelést fokozhatja az enteralis infekció antibiotikus kezelése [10]. A mechanizmusból következően a folyamat a behatás megszűnését követően fokozatosan leáll. Ugyanakkor a behatás súlyosságától függően az egyes szervekben és kiemelten a vesében maradandó károsodás alakulhat ki. Amennyiben a korai szakaszban jelentős vesefunkció-romlás volt megfigyelhető, akár teljes regresszió ellenére, évekkel később is kialakulhat hypertonia, proteinuria, illetve vesefunkció-romlás, ezért a betegek időszakos ellenőrzését biztosítani kell. A gyógyulást követően relapsus nincs [11]. Pneumococcus-fertőzéshez társuló HUS akut $S$. pneumoniae okozta fertőzést követően alakul ki, jellemzően 2 évnél fiatalabb gyermekeken. A baktérium által termelt neuraminidáz a vörösvértestek, a thrombocyták és az endothelsejtek glycocalixának felszínéről sziálsavat hasít le, aminek következtében az addig rejtett, úgynevezett Thomsen-Friedenreich (T)-antigének a felszínre kerülnek, és reakcióba lépnek a keringésben található reguláris anti-T-ellenanyagokkal. Differenciáldiagnosztikai szempontból fontos a vércsoportvizsgálat során észlelt Coombs-pozitivitás [11]. A betegség már eredendően súlyos, a leggyakrabban empyemával járó pneumoniában, meningitisben vagy otitisben szenvedő gyermekekben lép fel. A betegek gyógyulását követően relapsus nem ismert. Az esetek mintegy negyedében hypertonia, proteinuria, vesefunkció-beszúkülés, esetenként végállapotú veseelégtelenség maradhat vissza az akut fázis lezajlását követően [12].

\section{A KR primer, genetikai defektusai következtében kialakuló HUS}

A KR egyes összetevőinek örökletes hibája esetén fokozott a fertőzéses megbetegedések, illetve az autoimmun kórképek kialakulásának veszélye. A Clq, Clr/s, C2, C4 és a C3 hiánya elsősorban immunkomplexbetegségekre, a C3, C5, C6, C7, C8, C9 defektusa pedig légúti bakteriális fertőzésekre, bacteriaemiára és meningitisre hajlamosít. A KR szabályozófehérjéinek hibája az aktiválódásából származó specifikus tünetegyütteshez vezet. Így a Cl-inhibitor hiánya familiaris angiooedemát okozhat, az alternatív útvonal szabályozatlan aktivációjának következménye pedig thromboticus microangiopathia kialakulása lehet [1]. Az utóbbiakat primer immundefektusoknak tekintjük, hiszen azokat az immunrendszer integráns részét képező komplementfehérjék primer, genetikai károsodása okozza. Az aHUS-esetek több 
mint felének hátterében az alternatív út valamelyik komponensének autoszomális recesszív vagy domináns öröklődésmenetû primer defektusa, következésképpen a komplement alternatív útjának regulációs zavara áll [6, 7, 13]. A KR alternatív útjának jellemzője a folyamatos alacsony intenzitású C3-hasadás miatti spontán aktiváció, valamint az ezt felerôsítő pozitív visszacsatolás (úgynevezett amplifikáció). A szabályozófehérjék ennek a folyamatnak a féken tartásában játszanak döntő szerepet. Eddig a CFH, a H-faktor-szerü fehérjék (H factor related proteins 1-5, CFHRl-5), a CFI, az MCP, a CFB és a C3, valamint a thrombomodulin génjének mutációit írták le aHUS hátterében $[6,7,12]$. Az egyes mutációkon túlmenően a H-faktor regulátori múködését gátló autoantitest előfordulása is ismert. A CFH-ellenes antitest képződésének hátterében is genetikai hajlam áll, az esetek túlnyomó többségében kimutatható a CFHRl-et, illetve a CFHR3-at kódoló gén homozigóta deletiója. $\mathrm{Az}$ anti-CFH-autoantitestek a $\mathrm{H}$-faktor $\mathrm{C}$-terminális végéhez kötődve gátolják annak szabályozó hatását [14]. $\mathrm{Az}$ CFH, CFI, MCP és thrombomodulin mutációi funkcióvesztő mutációk, vagyis az érintett fehérje nem termelődik, vagy nem múködik. A CFB és a C3 esetében a szabályozófehérjék kapcsolódását és hatását gátló, a létrejött C3-konvertáz komplexet stabilizáló, funkciónyerő mutációkról van szó. Ennek következménye az alternatív út fokozott aktiválódása, szöveti károsodással [7, 15].

A komplementmediált aHUS-ra klinikailag a STECHUS-hoz képest lassabb progresszió és a gyakran hullámzó lefolyás jellemző. A betegséget megelőzheti banális légúti vagy enteralis fertőzés, az utóbbi differenciáldiagnosztikai nehézséget is jelent (elkülönítés a STECHUS-tól). A thrombocytaszám az esetek több mint felében $50 \mathrm{G} / 1$ feletti, lehet akár normális is (>150 G/1). Ilyenkor fontos a thrombocytaszám alakulásának időbeli követése, 25\%-nál nagyobb csökkenést kórjelzőként értékelünk. A klinikai képben az akut vesekárosodás mellett extrarenalis (neurológiai, cardialis, egyéb) tünet 10$30 \%$-a fordul elő $[4-6,14]$. Az igazoltan komplementmediált aHUS-betegek valamivel több mint felében azonosítható genetikai eltérés, amely gyakran összetett, egy vagy több ritka mutáció és ehhez kapcsolódóan egy vagy több rizikópolimorfizmus vagy haplotípus összeadódó hatásából áll. A komplex genetikai háttérből következően a mutációk penetranciája alacsony, körülbelül 40$50 \%$-os $[7,14,15]$.

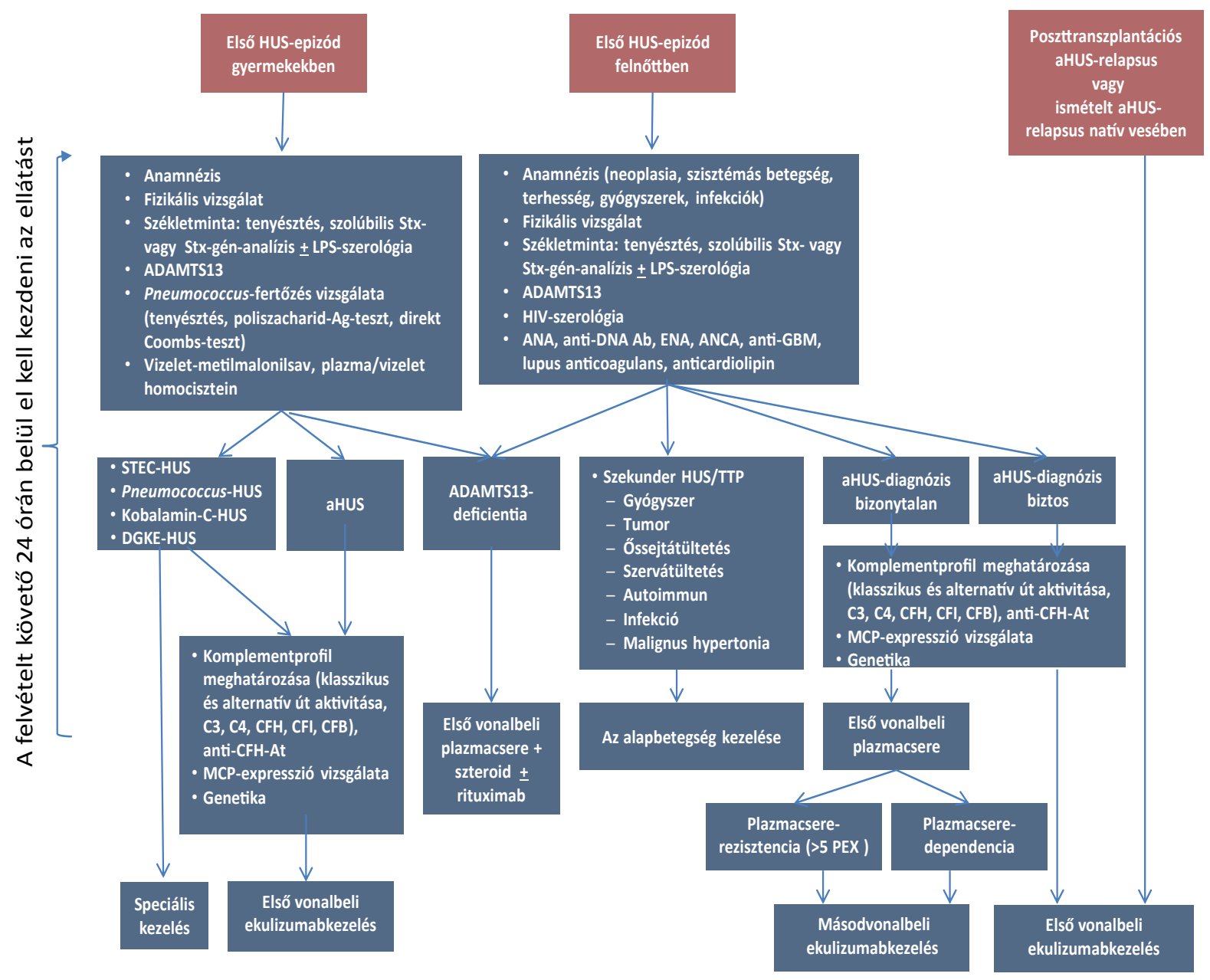

2. ábra

| A HUS diagnosztikus algoritmusa és a lehetséges terápiás módozatok összefoglalása [7] 


\section{Diagnosztikus konzekvenciák}

$\mathrm{Az}$ atípusos HUS kórismézése többlépcsős folyamat. Jelenleg nem rendelkezünk olyan kizárólagos, megfelelően érzékeny és specifikus vizsgálómódszerrel, amelynek segítségével rövid idő alatt igazolni lehetne az aHUS-t. Így a diagnózis felállítása részben kizárásos alapon, részben a klinikai és laboratóriumi eltérések együttes értékelése alapján történik. A komplementrendszer részletes funkcionális elemzése, az ezt követő genetikai vizsgálat magasan specializált laboratóriumban történik; az eredmények végső értékelése a laboratóriumi, a szövettani és a klinikai eredmények alapján összetett csapatmunkát igényel, ami csak erre szakosodott, gyakorlattal rendelkező centrumban áll rendelkezésre. A diagnosztika megkönynyítésére nemzetközi ajánlások és hazai irányelv állnak rendelkezésre $[6,7]$. Ezek alapján a diagnózis több lépésben állítható fel [6-8]. A diagnosztikus algoritmust és a lehetséges terápiás módozatokat a hazai irányelv [7] alapján a 2. ábrán mutatjuk be.

Először a HUS diagnózisát kell felállítanunk, majd el kell indítanunk a komplementdiagnosztikát. A szupportív terápia bevezetését megelözôen azért szükséges a vérvétel a $\mathrm{KR}$ állapotának felmérésére, mivel az esetlegesen szükséges transzfúzió, illetve faktorpótlás befolyásolja az eredményeket. A vérvételt követően természetesen elkezdhető a szupportív kezelés. Ki kell zárnunk az infekciós és az egyéb másodlagos HUS-kórformákat, valamint a TTP-t. Végül aHUS diagnózisa esetén el kell végeznünk a komplementkomponensekkel kapcsolatban rendelkezésre álló genetikai vizsgálatokat. Itt is le kell szögeznünk azonban, hogy a terápia elindításának nem előfeltétele a pontos genetikai diagnózis előzetes megléte $[6,7]$.

1. táblázat |A genetikai vizsgálat indoklása aHUS-ban $[6,7]$

MIKOR javasolt a genetikai vizsgálat aHUS-ban?

- Az aHUS első epizódja esetén:

- Ha nincs bizonyított kiváltó tényező (STEC, súlyos ADAMTS13-hiány vagy hyperhomocysteinaemia/metil-malonilsav-ürítés)

- Haladéktalanul szükséges

- HUS-visszaesés esetén

- HUS családi előfordulása

- Terhességi/post partum HUS

- De novo poszttranszplantációs HUS

- Genetikai vizsgálat kötelező aHUS-t követő veseelégtelenség miatti veseátültetés tervezésekor

MIÉRT javasolt a genetikai vizsgálat?

- A genetikai jellemzők ismerete szükséges:

- annak kimondására, hogy a betegség primer komplementdeficientia-e;

- a prognózis, a visszaesés kockázata és a progresszió meghatározására

- A család számára genetikai tanácsadáshoz

- A veseátültetés tervezéséhez:

- a donor kiválasztásához,

- az átültetést követő visszaesés megelőzésére kialakítandó protokoll meghatározásához,

- a kombinált máj-vese átültetésről való döntés megalapozásához

\section{A genetikai vizsgálatok indokoltsága és eredményei aHUS-ban}

A kórképről alkotott ismereteink bóvülésével az ismert genetikai mutációk és variánsok száma is egyre bővül. A genetikai vizsgálatok a $\mathrm{CFH}, \mathrm{CFI}, \mathrm{CD} 46, \mathrm{CFb}, \mathrm{C} 3$, THBD2, CFHRI-5 DNS-szekvencia-analízis a ritka és gyakori variációk azonosítására, valamint kópiaszámmeghatározásra irányulnak $[6,7,14,16]$. Genetikai vizsgálatok elvégzésekor figyelembe kell venni a betegség inkomplett penetranciáját, azaz azt, hogy azonos genetikai háttér sem feltétlenül vezet az aHUS kialakulásához. Ezen túlmenően csak olyan mutációk minősíthetők nagy biztonsággal kóroki hatásúnak aHUS esetén, amelyeket korábban már leírtak aHUS-betegekben (egészségesekben pedig nem igazolhatók), és káros funkcionális hatásuk igazolt $[14,15]$. Ennek megfelelően a genetikai tanácsadás során is igen körültekintően kell eljárnunk. A genetikai vizsgálatokkal kapcsolatos ajánlásokat az 1 . táblázatban mutatjuk be.

\section{Terápia}

Az aHUS-sal kapcsolatos elméleti és gyakorlati ismeretek bővülésével párhuzamosan szükséges a diagnosztikus és terápiás ajánlásuk rendszeres megújítása, frissítése [6-8, 16, 17]. Az aHUS patomechanizmusában az alternatív útvonal szabályozatlan aktiválódása központi szerepet játszik. A korábbi empirikus plazmaterápia (plazmacsere, illetve plazmainfúzió) részben a plazmában jelen levő kóros fehérjék eltávolítására, részben a faktorok pótlására irányult (CFH-ellenes ellenanyag eltávolítása; funkciónyeréses mutációkban a kóros fehérje eltávolítása). Tisztán faktorhiánnyal járó mutációk esetében a plazmacsere helyett a plazmatranszfúzió is hatásos lehetett $[7,16]$. A célzott, a KR gátlására irányuló biológiai terápia bevezetése [18] alapvetően megváltoztatta az aHUS-kezeléssel kapcsolatos szemléletünket. A korábban oki terápiának számító plazmacsere aHUS-ban már nem tekinthető korszerű, első vonalbeli kezelésnek $[6,7]$.

$\mathrm{Az}$ atípusos HUS célzott terápiájára humanizált monoklonális antitestet fejlesztettek ki, amely a komplementfehérjék közül a C5-öt ismeri fel, és a kötődés után megakadályozza a további aktivációt. Hatására a terminális reakcióút gátlása következik be, nem alakul ki a membránt károsító komplex (C5b-9), illetve nem jön létre az erősen kemotaktikus és gyulladáskeltő hatású C5a-anafilatoxin [19]. A kezelés hatása aHUS-ban azonos komplementmutációval járó, a CFH-ellenes antitestekkel rendelkező és a mutáció nélküli esetekben. Ugyanakkor a CFH-ellenes antitestek okozta aHUS-ban a plazmaterápia és a párhuzamos immunszuppresszív kezelés tartós remissziót hozhat, az ellenanyagok eliminálásával. Amennyiben egyéb, a KR-t érintő mutáció kizárható, nincs szükség fenntartó C5-gátló kezelésre [20]. Korán indított kezelés esetén nagyobb a vesemúködés helyreállásának valószínűsége [21]. Extrarenalis tünetek 
esetén a terápiát folytatni kell. A kezelést elméletileg élethosszig kell alkalmazni, kivéve, ha a szer hatástalannak bizonyul. Ennek kimondásához legalább 3 hónapos kezelés szükséges [22]. Az igen magas kezelési költségek, valamint a rendszeres infúziós kezelés okozta kellemetlenség elkerülése céljából folynak próbálkozások a szer adásának felfüggesztésével a stabil remisszó elérése után [23]. Ilyenkor nagyon szoros obszerváció szükséges, és a reaktiváció első jelére folytatni kell a kezelést. H-faktor-mutációkban és alacsony residualis GFR mellett azonban a kockázat még így is magas.

Az aHUS miatt kialakult veseelégtelenség nyomán veseátültetésen átesett betegekben korábban igen magas volt a recidívaarány. A vesefunkció romlását átültetést követően kialakuló visszaesés esetében a hagyományos plazmacsere nem tudta meggátolni [24]. Az átültetést megelőzően megkezdett, profilaktikusan alkalmazott plazmacsere mellett is $50 \%$ feletti volt a relapsus miatti graftvesztés aránya [22]. Ekulizumabvédelemben [18] az átültetés ma már biztonsággal elvégezhető $[6,7,18]$. Tekintettel azonban arra, hogy az aHUS-ra hajlamosító genetikai tényezók mellett maga az átültetés okozta ischaemiareperfúziós károsodás, az esetleges rejectio, az infekciók (CMV, EBV), az immunszuppresszív terápia (kalcineurininhibitorok) önmagukban is endothelkárosodásra hajlamosítanak, a C5-gátló terápia felfüggesztése veseátültetés után igen nagy kockázattal járhat $[6,7]$.

\section{Komplementgátlás és bakteriális fertözések}

A C5-szinten bekövetkező komplementgátlás nem gátolja a proximalis komplementaktivációt, amely nélkülözhetetlen a mikroorganizmusok opszonizációjához és az immunkomplexek eltakarításához. Ugyanakkor a terminális út gátlásának következtében bizonyos tokos batktériumokkal szembeni védekezés elégtelenné válik. Ennek megelőzésére a kezelés megkezdése előtt legalább 2 héttel a betegeket a Meningococcus-vakcinával oltani kell $[1,19,21]$. Két héten belül indított kezelésnél antibiotikumprofilaxist (penicillin $\mathrm{V}$ vagy makrolid) kell alkalmazni. A folyamatos antibiotikumprofilaxis fenntartását az indokolja, hogy az oltási immunizáció nem nyújt 100\%-os védelmet, és nem fed le minden patogéntörzset. Meningitisre utaló klinikai tünetek (lázzal kísért fejfájás és/vagy tarkómerevség, vagy fényérzékenység) esetén azonnal orvoshoz kell fordulniuk a betegeknek, mert ezek a jelek Meningococcus-fertőzésre utalhatnak. A 18 év alatti betegeket $H$. influenzae és Pneumococcus ellen is immunizálni kell [7].

\section{Komplementgátlás vagy májátültetés?}

A komplementfaktorok nagyobb részét a máj termeli. Így CFH-hiány esetén a máj- vagy a kombinált máj-vese átültetés oki kezelésnek minősül, mivel a májátültetéssel a CFH hiánya is megszúnik. A C5-gátló terápia bevezetése óta ennek a magas kockázatú beavatkozásnak a lét- jogosultsága megkérdőjeleződött. Bár sikeres átültetést követően a betegnek nincs szüksége a további gátlóterápiára, a továbbiakban immunszuppresszív kezelésre szorul. E kérdésben - kontrollált vizsgálatok hiánya miatt minden esetben egyéni mérlegelés szükséges [25, 26].

\section{Esetismertetés}

A következőkben két esetet ismertetünk, amelyek kimenetelét az időközben fejlődő laboratóriumi diagnosztika és a terápiás ismeretek jelentősen befolyásolták.

Első betegünk 2008-ban került klinikánkra. A 8 éves leányt hányás, kiszáradás miatt utalták be, a fizikális vizsgálatkor már feltúnt sápadtsága, testszerte petechiákat észleltünk. Laboratóriumi vizsgálataiból kiemelendő az alacsony hemoglobinszint ( $57 \mathrm{~g} / \mathrm{l})$, a thrombocytopenia (33 G/1). Szérumkreatinin-értéke emelkedett volt (207 mikromol/1), emellett oliguriás volt, vizeletében fehérje és masszív (makroszkópos) haematuria volt kimutatható. A haemolysis jelenlétét alátámasztotta az emelkedett LDH-értéke $(2233 \mathrm{U} / \mathrm{l})$, a perifériás kenetben pedig $10 \%$ felett láttunk fragmentocytákat. A fentiekre alapozva HUS diagnózisát állítottuk fel. Etiológia után kutatva székletbakteriológiai vizsgálata nem igazolta STEC jelenlétét. A komplementdiagnosztika alacsony C3-értéket mutatott $(\mathrm{C} 3: 0,23 \mathrm{~g} / \mathrm{l})$, a C4 értéke a normális alsó határán volt $(0,15 \mathrm{~g} / 1)$. A CFH-antigén-szint alacsony volt (<30 mg/l), ezért CFH-hiányt feltételezve kezdetben rendszeres plazmacserét, majd plazmainfúziós kezelést vezettünk be. A plazmainfúziókat kezdetben hetente, majd 2, végül 3 hetente alkalmaztuk. Ekkor az aHUS ismét fellángolt, és a beteg újabb plazmainfúziók ellenére nem került teljes remisszióba. Hullámzó lefolyás mellett végül végállapotú veseelégtelenség alakult ki. Vesepótló kezelést indítottunk (peritonealis dialízis, majd ismétlődő peritonitisek miatt hemodialízis). Mintegy fél évvel a betegség manifesztációját követően vált elérhetővé a CFH-ellenes antitest kimutatása, mely betegünknél pozitívnak bizonyult. A beteg 7 éven keresztül részesült vesepótló kezelésben. Közben megtörtént a komplementrendszer genetikai vizsgálata.

Egy CFHRI-3 deletio (amely anti-H-faktor-autoantitestek kialakulására hajlamosít), egy thrombomodulinmutáció (D486Y), egy CFHR5-mutáció (p.V110A), valamint egy $\mathrm{H}$-faktor-rizikó-polimorfizmus (c.-331C>T) együtt voltak igazolhatók a betegnél.

A thrombomodulinmutáció, amelyet korábban más aHUS-betegekben is leírtak [27], a fehérje azon funkcióját érinti, amely az I-faktor-mediált C3b-lebontásért felel, tehát az aHUS patogenezisében lényeges szerepet játszó alternatív út diszregulációját súlyosbítja. A rendelkezésre álló adatok alapján a CFHR-génben azonosított mutáció kóroki szerepe még nem tisztázott.

A fenti tényezők együttese tehető felelőssé betegünkben az aHUS kialakulásáért.

Ezen ismeretek birtokában 2017 őszén ekulizumabvédelemben a betegnél sikeres veseátültetés történt. A be- 
teg vesefunkciója stabil, thromboticus microangiopathia kialakulásának nincs jele, a komplementgátlás megfelelő, komplementaktivációra utaló jel nincs. Az immunszuppresszió mellett $\mathrm{H}$-faktor-ellenes antitestek nem mutathatók ki.

A másik aHUS-esetünkben 2012-ben diagnosztizáltuk a betegséget. Az ugyancsak 8 éves kislány anamnézise, fizikális tünetei és laboratóriumi jelei az első esethez igen hasonlóak voltak. Panaszai, tünetei: hányás, sápadtság, petechiák. Laboratóriumi leletek: Hgb: $86 \mathrm{~g} / \mathrm{l}$; thrombocyta: 23 G/l; kreatinin: 156 mikromol/1; LDH: 1894 U/l. A kenetben fragmentocyták voltak kimutathatók, a vizeletben proteinuria és haematuria volt jelen. A székletből STEC nem volt igazolható. Komplementvizsgálat: C3: 0,46 g/l; C4: 0,33 g/l; CFH-antigén: $98 \mathrm{mg} / \mathrm{l}$ (csökkent), ugyanakkor a $\mathrm{CFH}$-ellenes ellenanyag vizsgálata pozitív eredményt adott. Ennek birtokában a plazmacsere mellett immunszuppresszív kezelést alkalmaztunk: kezdetben intravénás ciklofoszfamid-lökéskezelést, majd (indikáción túli alkalmazás miatt OGYI-engedély birtokában) B-sejt-ellenes biológiai terápiát (CD20-ellenes antitest). Emellett a beteg remisszióba került, vesefunkcója normális, vizeleteltérése nincs, a CFH-ellenes antitest titere lecsökkent, és tartósan kimutathatatlan. A genetikai vizsgálat homozigóta CFHRlés heterozigóta CFHR3-deletiót igazolt.

\section{A két eset tanulságai}

1) A CFHRl, illetve - 3 deletiója (ismerten) CFH-ellenes antitest kialakulására hajlamosít.

2) Első esetünkben a hagyományos kezelés - a megfelelő fiziológiai háttér ismeretének híján (CFH-ellenes antitest) - nem lehetett adekvát. A genetikai háttér megismerése és a terápiás lehetőségek fejlődése végül lehetővé tette a sikeres veseátültetést.

3) Első esetünk rámutat továbbá arra, hogy a genetikai háttér gyakran komplex. A CFH-ellenes antitestek mellett a thrombomodulinmutáció is rizikófaktor, emellett a beteg további rizikóvariánst és polimorfizmust hordoz, ezért az antitestek eltúnése ellenére a beteg recidívarizikója komplementblokád nélkül nem elhanyagolható.

4) Második, CFH-ellenes antitestek jelenlétére visszavezethető esetünket sikeresen kezeltük a hagyományos plazmaterápiával és immunszuppresszióval, fenntartó kezelésre nem szorul.

Vesefunkciója normális és stabil.

Anyagi támogatás: A közleményhez kapcsolódó kutatómunka az NKFI 124549. számú pályázat támogatásával valósult meg.

A cikk végleges változatát a szerző elolvasta és jóváhagyta.

Érdekeltségek: A szerzőnek nincsenek érdekeltségei.

\section{Köszönetnyilvánítás}

Köszönettel tartozom Prohászka Zoltánnak a betegeink ellátásához nyújtott magas szintű diagnosztikus segítségért és azért, hogy megteremtette az aHUS hazai ellátásának elméleti és gyakorlati hátterét.

\section{Irodalom}

[1] Prohászka Z, Vivarelli M, Reusz GS. Complement-mediated glomerular injury in children. In: Avner ED, Harmon WE, Niaudet P, et al. (eds.) Pediatric nephrology. Springer-Verlag, BerlinHeidelberg, 2014; pp: 927-958.

[2] Noris M, Remuzzi G. Hemolytic uremic syndrome. J Am Soc Nephrol. 2005; 16: 1035-1050.

[3] Kavanagh D, Goodship TH, Richards A. Atypical hemolytic uremic syndrome. Semin Nephrol. 2013; 33: 508-530.

[4] Prohászka Z. Haemolytic uremic syndrome and thrombotic thrombocytopenic purpura: Classification based on molecular etiology and review on recent developments of diagnostics. [A hemolitikus urémiás szindróma és a trombotikus thrombocytopeniás purpura molekuláris szemléletû klasszifikációja és diagnosztikájuknak aktuális kérdései.] Orv Hetil. 2008; 149: 1251-1261. [Hungarian]

[5] Szabó MZs, Réti M, Reusz Gy. Recent developments in the diagnosis and therapy of haemolytic uremic syndrome. Part 1: Diagnosis and initial therapy. [A haemolyticus uraemiás szindróma diagnosztikájának és terápiájának aktuális kérdései. 1. rész. Diagnosztika és kezdeti terápia.] Hyperton Nephrol. 2010; 14: 223229. [Hungarian]

[6] Loirat C, Fremeaux-Bacchi V. Atypical hemolytic uremic syndrome. Orphanet J Rare Dis. 2011; 6: 60.

[7] Ministry of Human Capacities. Guideline for the treatment of thrombotic thrombocytopenic purpura (TTP) and hemolytic uremic syndrome (HUS). [EMMI szakmai irányelv a thrombotikus thrombocytopeniás purpura (TTP) és a haemolytikus uraemiás syndroma (HUS) kezeléséről. Egészségügyi Közlöny 2017/2. Azonosító: 002019.] Orv Hetil. 2017; 158(Suppl 2): 1-44. [Hungarian]

[8] Prohászka Z, Szilágyi Á, Réti M, et al. Recent developments in the diagnosis and therapy of haemolytic uremic syndrome. Part 2: Aspects of long-term treatment and prognosis. [A haemolyticus uraemiás szindróma diagnosztikájának és terápiájának aktuális kérdései. 2. rész. A betegek hosszú távú kezelésének és gondozásának szempontjai.] Hyperton Nephrol. 2011; 15: 101-109. [Hungarian]

[9] Keir LS, Marks SD, Kim JJ. Shigatoxin-associated hemolytic ure mic syndrome: current molecular mechanisms and future therapies. Drug Des Devel Ther. 2012; 6: 195-208.

[10] Tarr IP, Gordon CA, Chandler WL. Shiga-toxin-producing Escherichia coli and haemolytic uraemic syndrome. Lancet 2005; 365: 1073-1086.

[11] Rosales A, Hofer J, Zimmerhackl LB, et al., for the GermanAustrian HUS Study Group. Need for long-term follow-up in enterohemorrhagic Escherichia coli-associated hemolytic uremic syndrome due to late-emerging sequelae. Clin Infect Dis. 2012; 54: 1413-1421.

[12] Waters AM, Kerecuk L, Luk D, et al. Hemolytic uremic syndrome associated with invasive pneumococcal disease: the United Kingdom experience. J Pediatr. 2007; 151: 140-144.

[13] Fremeaux-Bacchi V, Fakhouri F, Garnier A, et al. Genetics and outcome of atypical hemolytic uremic syndrome: a nationwide French series comparing children and adults. Clin J Am Soc Nephrol. 2013; 8: 554-562.

[14] Blanc C, Togarsimalemath SK, Chauvet S, et al. Anti-factor H autoantibodies in $\mathrm{C} 3$ glomerulopathies and in atypical hemolytic uremic syndrome: one target, two diseases. J Immunol. 2015; 194: 5129-5138. 
[15] Bu F, Maga T, Meyer NC, et al. Comprehensive genetic analysis of complement and coagulation genes in atypical hemolytic uremic syndrome. J Am Soc Nephrol. 2014; 25: 55-64.

[16] Ariceta G, Besbas N, Johnson S, et al., for the European Paediatric Study Group for HUS. Guideline for the investigation and initial therapy of diarrhea negative hemolytic uremic syndrome. Pediatr Nephrol. 2009; 24: 687-696.

[17] Johnson S, Stojanovic J, Ariceta G, et al. An audit analysis of a guideline for the investigation and initial therapy of diarrhea negative (atypical) hemolytic uremic syndrome. Pediatr Nephrol. 2014; 29: 1967-1978.

[18] Zimmerhackl LB, Hofer J, Cortina G, et al. Prophylactic eculizumab after renal transplantation in atypical hemolytic-uremic syndrome. N Engl J Med. 2010; 362: 1746-1748.

[19] Soliris. Summary of product characteristics. [Soliris (ekulizumab), alkalmazási elöirat.] https://ec.europa.eu/health/documents/ community-register/2016/20160919135986/anx_135986_ hu.pdf [Hungarian]

[20] Sinha A, Gulati A, Saini S, et al., for the Indian HUSR Registry. Prompt plasma exchanges and immunosuppressive treatment improves the outcomes of anti-factor $\mathrm{H}$ autoantibody-associated hemolytic uremic syndrome in children. Kidney Int. 2014; 85: 1151-1160.

[21] Zuber J, Fakhouri F, Roumenina LT, et al., on behalf of the French Study Group for aHUS/C3G. Use of eculizumab for atypical haemolytic uraemic syndrome and C3 glomerulopathies. Nat Rev Nephrol. 2012; 8: 643-657.
[22] Sevinc M, Basturk T, Sahutoglu T, et al. Plasma resistant atypical hemolytic uremic syndrome associated with a $C F H$ mutation treated with eculizumab: a case report. J Med Case Rep. 2015; 9: 92.

[23] Ardissino G, Testa S, Possenti I, et al. Discontinuation of eculizumab maintenance treatment for atypical hemolytic uremic syndrome: a report of 10 cases. Am J Kidney Dis. 2014; 64: 633637.

[24] Le Quintreca M, Zuber J, Moulin B, et al. Complement genes strongly predict recurrence and graft outcome in adult renal transplant recipients with atypical hemolytic and uremic syndrome. Am J Transplant. 2013; 13: 663-675.

[25] Saland JM, Ruggenenti P, Remuzzi G, et al. Liver-kidney transplantation to cure atypical hemolytic uremic syndrome. J Am Soc Nephrol. 2009; 20: 940-949.

[26] Coppo R, Bonaudo R, Peruzzi RL, et al. Liver transplantation for aHUS: still needed in the eculizumab era? Pediatr Nephrol. 2016; 31: 759-768.

[27] Delvaeye M, Noris M, De Vriese A, et al. Thrombomodulin mutations in atypical hemolytic-uremic syndrome. N Engl J Med. 2009; 361: 345-357.

(Reusz György dr., Budapest, Bókay J. u. 53-54., 1083 e-mail: reusz.gyorgy@med.semmelweis-univ.hu)

Új fejlesztés az egészségügyben dolgozók, tanulók részére!

\section{A magyar nyelvứ szakirodalmi keresőszolgáltatás}

\section{Mi a NOTA?}

Napivizit Orvosi Tudástár Alkalmazás

Mit tud a NOTA portál?

Megkönnyíti a magyar nyelvű szakirodalmi források keresését.

Eszköztöl függetlenül, akár okostelefonról, a betegágy mellett állva is használható.

\section{Miben kereshet a NOTA-val?}

Az Akadémiai Kiadó folyóirataiban: Orvosi Hetilap, Magyar Sebészet, Mentálhigiéné és Pszichoszomatika.

Más kiadók magyar nyelvü szakfolyóirataiban: pl. Lege Artis Medicinae, Hypertonia és Nephrologia, Ideggyógyászati Szemle.

A hatályos szakmai irányelvekben.

Magyar nyelvủ kérdésekre adott angol nyelvű találatokban, a PubMeden.

\section{nota.hu}

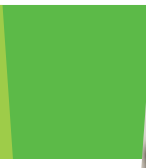

\section{Akadémiai Kiadó}

A Wolters Kluwer Csoport tagja

1117 Budapest, Prielle Kornélia u. 21-35. / Telefon: (1) 464-8246

www.akademiai.hu / www.akademiai.com

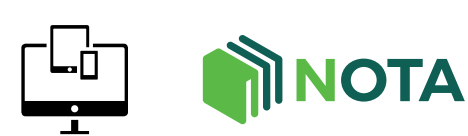

AKADÉMIAI KIADÓ 